\title{
Knowledge and health beliefs assessment of Sickle cell disease as a prelude to neonatal screening in Ibadan, Nigeria
}

\author{
Oluwatoyin A Babalola', Christina S Chen², Biobele J Brown', John F. Cursio ${ }^{3}$, Adeyinka G Falusi ${ }^{1}$, \\ Olufunmilayo I Olopade ${ }^{4}$ \\ ${ }^{1}$ College of Medicine, University of Ibadan, Nigeria, ${ }^{2}$ Pritzker School of Medicine, University of Chicago, Illinois, USA, ${ }^{3}$ Department of Public Health \\ Sciences, University of Chicago, Illinois, USA, ${ }^{4}$ Department of Medicine (Hematology/Oncology), University of Chicago, Chicago, Illinois, USA \\ Keywords: global health \\ https://doi.org/10.29392/joghr.3.e2019062
}

\section{Journal of Global Health Reports}

Vol. 3, 2019

\begin{abstract}
Background
Nigeria bears the highest burden of sickle cell disease (SCD) in the world. Neonatal screening programmes for SCD in other countries have been associated with remarkable reductions in mortality and morbidity. In Nigeria, there is an ongoing effort to implement a large scale SCD neonatal screening program with long-term follow-up. This study was conducted to assess the adequacy of knowledge and perspectives of the target population with regard to newborn screening for sickle cell disease and also to identify likely barriers and challenges to the successful implementation of the programme.
\end{abstract}

\section{Methods}

Two hundred and five mothers of young infants ( $\leqslant 2$ months old) and 181 mothers of SCD affected children were recruited from primary, secondary and tertiary health facilities in Ibadan, south-western Nigeria over a period of six weeks. Questionnaires were administered to the mothers assisted by a translator where necessary, in order to determine some of the factors influencing the mothers' knowledge and perspectives towards SCD and their decision to accept neonatal screening. T-test was used to compare means of scores. Chi-square test was used to test associations between differences in proportions. Univariate and multivariate analyses were used to determine which factors could influence baseline knowledge about SCD. Multiple logistic regression using stepwise selection was used to determine which factors were important in predicting the acceptance of neonatal screening by the mothers.

\section{Results}

Higher level of education of the mothers $(P=0.013)$ and having an affected child $(P<0.001)$ were the major factors associated with increased knowledge base and healthy perspectives towards SCD. Fewer than $50 \%$ of the mothers had moderate knowledge of SCD and its genetic inheritance, and had also heard of neonatal screening for SCD diagnosis before the survey. Two-thirds of mothers of the young infants were willing to have their babies or future children screened and most would prefer the babies be screened at an immunization center rather than at birth centers $(P<0.001)$. Awareness of, and perspectives towards SCD and neonatal screening influenced the mothers' acceptance of screening for their babies $(P<0.05)$. In addition, many of the mothers would need permission from their husbands or a relative to have their babies screened.

\section{Conclusion}

Large scale awareness on the part of the community about SCD and the benefits of neonatal screening is necessary for successful implementation of the planned neonatal screening programme. Government funding and support for community education along with facilities for programme implementation are needed to kick off the program in Ibadan, Nigeria.

In Nigeria, sickle cell disease (SCD) is the most prevalent genetic disease with over 4 million individuals affected. ${ }^{1}$ Approximately $25 \%$ of the population are carriers of the sickle cell trait, and the birth incidence of the disease is 20 per 1000 live births. The World Health Organization estimates that 150,000 SCD children are born annually in Nige- 
ria, and about 100,000 of these children die. ${ }^{2}$ SCD patients are at greatest risk for death in the first 5 years of life with approximately $50 \%$ of deaths occurring between the ages of 6 months and 1 year. ${ }^{3}$ Newborn screening programmes in developed countries that allow for early identification of SCD and appropriate management have been shown to reduce SCD morbidity and mortality. ${ }^{4-6}$ In Jamaica, screening of neonates has led to improved outcomes in affected babies. ${ }^{7}$ In Brazil, newborn screening for SCD started as far back as 1992 in Sao Paulo State, and by the end of the year 2000 , almost 300,000 babies had been screened in 78 institutions across 36 municipalities. This resulted in knowledge of the incidence of SCD in the population. ${ }^{8}$

SCD is a blood disorder in which the sickling allele for haemoglobin is inherited in the homozygous state or with another abnormal gene in haemoglobin structure or production. ${ }^{9}$ Sickled red blood cells (RBCs) are unable to pass through capillary beds and are destroyed within 10-17 days in comparison to the normal 120-day lifespan of non-sickled RBCs, leading to chronic anaemia. ${ }^{10}$ Chronic haemolysis can lead to jaundice, formation of pigment gall stones ${ }^{10,11}$ and pulmonary hypertension, which is a major risk factor for death in SCD patients. ${ }^{12}$ Obstruction of blood flow in small vessels by sickled cells can also lead to serious complications of ischemia or necrosis in all of the major organs, dactylitis, and hypersplenism. ${ }^{10,11}$ Approximately $11 \%$ of SCD patients experience a stroke by the age of 30.13 SCD may also affect the respiratory system resulting in acute chest syndrome and chronic sickle lung disease. These are leading causes of death and hospitalization for all ages of SCD. 14

Medical management of SCD includes antibiotic prophylaxis against Streptococcus pneumonia infection, one of the early life-threatening complications of untreated disease, anti-malarial drugs, specific vaccinations, folic acid supplementation, and continual follow-up. ${ }^{15,16} \mathrm{~A}$ benefit of screening is that, identification of SCD in the newborn empowers parents to learn about early treatment and prevention of complications before the SCD manifests symptomatically. On the African continent, while there have been successful screening programs established in Ghana and the Republic of Benin, there is no established neonatal screening program for SCD in Nigeria, which has the largest burden (about 20\%)of SCD globally. ${ }^{17}$ In order to reduce SCD morbidity and mortality through a comprehensive newborn screening and healthcare management program in Nigeria, it is necessary for mothers to know about SCD and the value of neonatal screening. In a previous study in Nigeria that examined newborn screening for SCD in Benin City, 99.7\% of 630 mothers accepted screening. That is, they had their babies tested for SCD, revealing a3\% prevalence in the babies. ${ }^{18}$ The University College Hospital in Ibadan, Nigeria has been preparing to implement a large scale SCD neonatal screening program with long-term follow-up.

The aim of this study was to assess the adequacy of knowledge of the programme's target population with regard to SCD and newborn screening for SCD and also to identify likely barriers and challenges to the successful implementation of the programme in Ibadan, Nigeria. This would facilitate adequate preparation for the proposed program and hopefully guide implementation of neonatal screening programmes, nationwide.We hypothesized that the basic knowledge and perceptions of the target population about SCD and neonatal screening would determine the level of uptake of the proposed neonatal screening programme. Acceptance in the present study was defined as willingness of the mothers to have their babies screened whenever the planned programme would be established.

\section{MATERIALS AND METHODS}

\section{HEALTH CARE SETTING}

The health care system in Nigeria comprises three levels: primary, secondary and tertiary. Primary health care facilities provide general health services of a preventive, curative, promotive and rehabilitative nature to the population as the entry point to the health care system. Secondary health care facilities provide specialized services to patients referred from the primary health care level. Such specialized services are provided to general medical, surgical, pediatric, obstetrics and gynaecology patients through outpatient and in-patient services of hospitals and through community health services. Adequate specialized supportive services, such as laboratory, diagnostic, blood bank, rehabilitation, and physiotherapy, are provided. Tertiary health care facilities provide highly specialized services. These are teaching hospitals and other special hospitals that provide care for specific disease conditions or specific groups of patients. ${ }^{19}$

\section{STUDY DESIGN}

This is a multi-center, prospective, cross-sectional study of two populations. The primary group consisted of mothers of babies under two months old at five immunization health centres in Ibadan, none of whom was known to have any children with SCD. The five healthcare centres included two primary facilities (Idiogugu Health Center and Oniyanrin Health Center), two secondary facilities (Oni Memorial Children's Hospital and Adeoyo Maternity Center) and a tertiary facility (University College Hospital). The secondary group in the study consisted of mothers who are already care-givers of SCD-affected children who receive care at the two secondary facilities (Oni Memorial Children's Hospital and Adeoyo Maternity Center) and the tertiary health centre (University College Hospital in Ibadan).

\section{STUDY PROCEDURE}

A total of 415 mothers at these facilities participated. Any family member that was not the mother of the young infant or child with SCD was excluded from the study. For the mothers of young infants (primary group), exclusion criteria included already having an older child with SCD. For the mothers of children with SCD (secondary group), exclusion criteria also included being involved with SCD childcare for less than 6 months. The purpose of the study was explained to all recruits in English and the local Nigerian language of Yoruba. Recruits gave fully informed, written consents before participating. The study protocol was approved by the Ethics Review Committee of the University of Ibadan, Nige- 
ria and the Institutional Review Board of the University of Chicago.

A questionnaire on paper, consisting of open-ended and close-ended questions was administered in the waiting areas for immunization or in check-up clinics. The questionnaire consisted of 51 items, including some to collect sociodemographic information, a multiple choice questions to assess SCD knowledge, a Likert scale assessment of health beliefs towards SCD, and questions on the acceptability of, and barriers to future neonatal screening for SCD. Participants who were literate in English filled out the questionnaire independently, with a final check by an administrator for completeness. Participants fluent only in Yoruba had an individual translator read through each item in the local language and assist in recording each response in English. Translators were trained in advance, using a sample questionnaire, to assure consistency in translation and recording.

\section{STATISTICAL ANALYSIS}

The knowledge questions were scored on a binary scale with a score of 1 for a correct answer and 0 for an incorrect answer. Level of education was categorized as being at one of three levels ${ }^{1}$ : less than senior secondary education (those with junior secondary, primary and Quranic education and those with no formal education), ${ }^{2}$ senior secondary education, or ${ }^{3}$ tertiary education. Statistical analyses were performed using IBM SPSS (version 25) (IBM, Armonk, NY, USA) and SAS (version 9.4) (SAS Institute, Cary, NC, USA) softwares. T-test was used to compare means of scores. $X-2$ tests were used to compare frequencies and to test associations between differences in proportion with a level of significance set at $P<0.05$. Univariate and multivariate analyses were used to determine which factors could influence baseline knowledge about SCD. Multiple logistic regression using stepwise selection was used to determine which factors were important in predicting the acceptance of neonatal screening by the mothers.

\section{RESULTS}

\section{PARTICIPANT DEMOGRAPHICS}

A total of 415 questionnaires were completed over the course of six weeks at the five healthcare centres. Of these, 29 questionnaires (7\%) were excluded from analysis due to incompleteness or failure of participants to meet inclusion criteria. Out of the remaining 386 questionnaires analyzed, 205 were completed by mothers of young infants $(0-2$ months) and 181 were completed by mothers of children affected by SCD. In the mothers of infants group, the median age was 30 years (range: 18 - 42 years). The median age of mothers of children with SCD was 38 years (range: 23 - 70 years). Table 1 summarizes the characteristics of the mothers surveyed. Chi-square test and Fisher's exact tests revealed no significant differences between the two groups in terms of level of education $(P=0.09)$ or religion $(P=0.46)$. Most of the participants $(81 \%)$ had finished senior secondary or higher education and 204 (53\%) self-identified as Christian while 179 (47\%) as Muslim.

\section{ASSESSMENT OF KNOWLEDGE ABOUT SCD}

There were twelve multiple choice knowledge assessment questions about the cause, heritability, symptoms and treatment of SCD. Each answer was given a score of 1 or 0 , as explained previously, and the scores summed. A total score of $\geqslant 6$ was taken as a moderate knowledge of SCD. Mothers of children with SCD scored significantly higher $(P<0.001)$ on the knowledge assessment than mothers of infants. The average score for mothers of children with SCD was $6.7 \pm 2.2$ while that of mothers of young infants was 4.0 \pm 2.6 . The two highest scoring questions were on defining SCD as a blood disorder and knowing which combinations of haemoglobin genotypes in marriage will not result in a child with SCD. Differences in the performances of the two groups of women on each of the knowledge questions was determined by $\chi^{2}$ (Table 2 ).

Most mothers in both groups thought the hemoglobin (Hb) genotype SS is the only form of SCD: 120 (58.5\%) of mothers of young infants and 146 (80.7\%) of mothers of affected children. Most were not aware that inheriting the mutant $\mathrm{C}$ hemoglobin with the $\mathrm{S}$ hemoglobin can also result in SCD. Twenty-five percent of the mothers who already had children affected with SCD in this study did not understand how SCD is inherited. Ninety (49.7\%) mothers of affected children knew only of genotype SS as a form of SCD, while 74 (40.9\%) knew that the genotype SC is a form of SCD as well, and 6 (3.3\%) of these mothers had no knowledge of the genotypes that cause SCD (Fisher's exact test = $56.3, P<0.001)$. This contrasted with the mothers of young infants, only 30 (14.6\%) of whom knew that the genotype SC is also a form of SCD and 43 (21\%) of whom did not know about the genotypes that cause SCD.

A slight majority of mothers of young infants $(n=108$, $52.7 \%)$ and a few mothers of affected children ( $n=34,18.8 \%)$ could not identify blood testing as the best means of SCD diagnosis. Most mothers of young infants $(n=167,81.5 \%)$ and the majority of mothers of affected children $(n=105$, $58 \%$ ) did not know SCD is likely to start manifesting between six and nine months.

The majority of the mothers in both groups identified severe debilitating pain as the only symptom of SCD. A large proportion could not identify complications associated with SCD. Only 31 (15.1\%) mothers of young infants could identify severe debilitating pain, stroke, infections and organ damage as all being symptoms or complications of SCD. A larger proportion of these mothers (34.1\%) knew about severe debilitating pain only, while 46 (22.4\%) did not know about SCD symptoms at all. While fifty (27.6\%) of mothers of affected children could identify all the symptoms, a much larger proportion, 104 (57.5\%), identified only severe debilitating pain. Eleven $(6.1 \%)$ of the mothers of affected children did not indicate any SCD symptom (Fisher's exact test $=60.5, P<0.001)$.

Fifty-five (26.8\%) mothers of young infants knew that jaundice, bone pains, and anemia requiring blood transfusion were all common features in affected individuals, while a larger proportion, 111 (61.3\%), of mothers of affected children knew about all these complications. Some mothers of young infants thought only jaundice $(n=46$, $22.4 \%)$ or only bone pain $(n=4,26.3 \%)$ were the common 
Table 1. Demographic characteristics of mothers of young infants and mothers of children with SCD.

\begin{tabular}{|c|c|c|c|}
\hline & $\begin{array}{l}\text { Mothers of young infants } \\
(n=205), \text { mumber }(\%)\end{array}$ & $\begin{array}{l}\text { Mothers of children with SCD } \\
\quad(n=181), \text { number }(\%)\end{array}$ & Statistical test \\
\hline Age (years): & & & Fisher's exact test \\
\hline $16-25$ & $48(23.4)$ & $5(2.8)$ & $133.73, P<0.001$ \\
\hline $26-35$ & $131(63.9)$ & $61(33.7)$ & \\
\hline $36-45$ & $24(11.7)$ & $87(48.1)$ & \\
\hline$>45$ & $0(0)$ & $26(14.4)$ & \\
\hline Marital status: & & & Fisher's exact test \\
\hline Single & $2(1.0)$ & $5(2.8)$ & $10.48, P=0.008$ \\
\hline Married & $203(99.0)$ & $168(92.8)$ & \\
\hline Divorced & $0(0)$ & $2(1.1)$ & \\
\hline Widowed & $0(0)$ & $1(0.6)$ & \\
\hline Separated & $0(0)$ & $5(2.8)$ & \\
\hline Number of children: & & & Pearson $x^{2}$ \\
\hline 1-2 children & $135(65.8)$ & $55(30.4)$ & $50.4, P<0.001$ \\
\hline 3-4 children & $63(30.7)$ & $101(55.8)$ & \\
\hline 5-6 children & $7(3.4)$ & $24(13.3)$ & \\
\hline Level of education: & & & Pearson $x^{2}$ \\
\hline$<$ Senior secondary & $33(16.1)$ & $38(21.0)$ & $2.88, P=0.242$ \\
\hline Senior secondary & $91(44.4$ & $66(36.5)$ & \\
\hline Tertiary & $81(39.5$ & $76(42.0)$ & \\
\hline Spouse's level of education: & & & Pearson $x^{2}$ \\
\hline <Senior secondary & $11(5.4)$ & $22(12.2)$ & $7.429, P=0.025$ \\
\hline Senior secondary & $87(42.4)$ & $60(33.3)$ & \\
\hline Tertiary & $107(52.2$ & $98(54.4)$ & \\
\hline Religion: & & & Pearson $x^{2}$ \\
\hline Christianity & 104 & 98 & $0.543, P=0.474$ \\
\hline Islam & 100 & 81 & \\
\hline
\end{tabular}

features of SCD. Thirty-four (18.7\%) and 27 (14.9\%) of mothers of affected children, respectively, thought likewise (Fisher's exact test $=59.2, P<0.001$ ).

\section{HEALTH BELIEFS}

This section of the questionnaire was made up of twelve Likert scale items. These were statements about the severity of SCD, knowledge of the risk of having children with the disease, the benefits of knowing one's carrier status and barriers to genotype testing. Beliefs were assessed using a Likert scale of $1-5$, where a score of 1 indicated 'strongly disagree', 2 - 'disagree', 3 - 'undecided', 4 - 'agree', and 5 - 'strongly agree'. Responses of mothers in the primary and secondary groups to the health beliefs statements are shown in Table 3 .

About $76 \%$ of secondary group mothers admitted that before having their first child with SCD, they were not aware that their children were at risk of having the disease. However, about $20 \%$ of the mothers in both groups agreed that they were aware. Forty-three percent of primary group mothers and $21 \%$ of secondary group mothers reported that knowing their child's risk for SCD would not impact how they plan a pregnancy. A majority of mothers in the secondary group (69.4\%) were not aware that their spouses were carriers of the sickle cell trait while about $22 \%$ was aware. Many more primary group mothers (32\%) were indifferent and also disagreed with the notion that it is useful to know if they have the sickle cell trait compared with $18.8 \%$ of secondary group mothers $(P=0.008)$. As for knowing the sickle cell trait status of one's spouse, $16.3 \%$ of mothers of young infants and $6.6 \%$ of mothers of affected children strongly disagreed that there is any benefit $(P=0.008)$.In measuring likely barriers to haemoglobin genotype testing, $22.4 \%$ of mothers of young infants were of the opinion that testing for sickle cell disease is painful and difficult while $33.1 \%$ of mothers of affected children were of the same opinion $(P=0.001)$. About $25-30 \%$ of mothers in both groups together agreed that it would be difficult to convince their spouses to have testing $(P=0.195)$. About $17.5 \%$ of mothers of young infants and $25 \%$ of mothers of affected children believed screening a child for sickle cell disease would be expensive while $19 \%$ and $7.2 \%$ in the two groups respectively were uncertain $(P=0.004)$.

\section{ACCEPTANCE OF, AND BARRIERS TO NEONATAL TESTING}

Almost all (91.2\%) the mothers of affected children knew their own haemoglobin genotype and $90 \%$ knew that of 
Table 2. Proportion of women in both groups with correct answers to the knowledge assessment questions on SCD.

\begin{tabular}{|c|c|c|c|c|}
\hline & Knowledge assessment questions & $\begin{array}{c}\text { Mothers of } \\
\text { young infants } \\
\text { (n=205), } \\
\text { number (\%) }\end{array}$ & $\begin{array}{l}\text { Mothers of } \\
\text { children with } \\
\text { SCD ( } n=181) \text {, } \\
\text { Number (\%) }\end{array}$ & $x^{2}$ test \\
\hline 1. & $\begin{array}{l}\text { Sickle cell disease is caused by (Ans: inheriting genes from } \\
\text { both parents) }\end{array}$ & 99 (48.3\%) & 153 (84.5\%) & $\begin{array}{l}58.3 \\
P<0.001\end{array}$ \\
\hline 2. & $\begin{array}{l}\text { How many genes must someone inherit to have SCD? (Ans: } \\
\text { two, one from their mom, and one form their dad) }\end{array}$ & 87 (42.4\%) & 137 (75.6\%) & $\begin{array}{c}43.6 \\
P<0.001\end{array}$ \\
\hline 3. & $\begin{array}{l}\text { Sickle cell disease can cause (Ans: severe debilitating pain, } \\
\text { strokes, infections and organ damage) }\end{array}$ & 31 (15.1\%) & $50(27.6 \%)$ & $\begin{aligned} & 9.1 \\
P= & 0.003\end{aligned}$ \\
\hline 4. & $\begin{array}{l}\text { Sickle cell disease occurs most often in (Ans: people of African } \\
\text { descent) }\end{array}$ & $46(22.4 \%)$ & $31(17.1 \%)$ & $\begin{array}{l}1.7 \\
P=0.192\end{array}$ \\
\hline 5. & $\begin{array}{l}\text { Sickle cell pain can feel worse than (Ans: toothache, severe } \\
\text { headache and labour pains) }\end{array}$ & $79(38.5 \%)$ & $105(58.0 \%)$ & $\begin{array}{c}14.6 \\
P<0.001\end{array}$ \\
\hline 6. & SCD is a (Ans: blood disorder) & $129(62.9 \%)$ & $162(89.5 \%)$ & $\begin{array}{c}36.6 \\
P<0.001\end{array}$ \\
\hline 7. & SCD may easily be cured by (Ans: stem cell transplant) & $18(8.8 \%)$ & $27(14.9 \%)$ & $\begin{array}{c}4.7 \\
P=0.94\end{array}$ \\
\hline 8. & $\begin{array}{l}\text { What is the best way to know if someone has SCD? (Ans: with } \\
\text { a simple blood test) }\end{array}$ & 97 (47.3\%) & 147 (81.2\%) & $\begin{aligned} & 47.5 \\
P & <0.001\end{aligned}$ \\
\hline 9. & $\begin{array}{l}\text { At what age does SCD usually start manifesting? (Ans: from } 6 \\
-9 \text { months of age) }\end{array}$ & 38 (18.5\%) & $76(42 \%)$ & $\begin{aligned} & 25.4 \\
P & <0.001\end{aligned}$ \\
\hline 10. & $\begin{array}{l}\text { Which of the following are common features in persons with } \\
\text { SCD? (Ans: yellow eyes (jaundice), bone pains and low blood } \\
\text { level requiring blood transfusion) }\end{array}$ & 55 (26.8\%) & $111(61.3 \%)$ & $\begin{array}{c}46.9 \\
P<0.001\end{array}$ \\
\hline 11. & $\begin{array}{l}\text { Which of the following are forms of SCD (Ans: Hemoglobin SS } \\
\text { and SC) }\end{array}$ & 30 (14.6\%) & 74 (40.9\%) & $\begin{array}{c}33.8 \\
P<0.001\end{array}$ \\
\hline 12. & $\begin{array}{l}\text { Which of the following combinations of hemoglobin } \\
\text { genotypes in marriage will not result in a child with SCD? } \\
\text { (Ans: AS/AA) }\end{array}$ & $120(58.5 \%)$ & 146 (80.7\%) & $\begin{array}{l}27.299 \\
P<0.001\end{array}$ \\
\hline
\end{tabular}

Ans - answer, SCD - sickle cell disease

their husband, while $76.1 \%$ of mothers of young infants knew theirs and $66.3 \%$ knew that of their husband $\left(\chi^{2}=P<0.001\right)$. The full distribution of genotypes of the mothers is shown in Figure 1. More than half of the mothers of young infants attending primary health facilities did not know their genotype nor that of their husband. About 5\% - SS (2\%), SC (3\%) - of the caregivers were patients themselves.

The responses of women in both groups to questions on acceptability of, and barriers to neonatal screening for SCD are shown in Table 4. One hundred and fifty-one (83.4\%) mothers of affected children had raised 1 child with SCD, 25 (13.8\%) had raised two children with SCD, and 3 (1.7\%) had raised three children with SCD. Only 88 (42.9\%) mothers of young infants and 84 (46.4\%) mothers of affected children had heard of neonatal testing for SCD diagnosis before the survey $(P=0.46)$. The proportion of mothers of affected children (92.8\%) who were willing to accept neonatal testing was significantly higher than the proportion of mothers of young infants $(64.9 \%)(P<0.001)$.The most commonly stated reasons for neonatal diagnosis of SCD are knowing their child's genotype, knowing how to take care of their child early, and for peace of mind. Out of the 13 (7.2\%) mothers of affected children who were not willing to have their babies screened, seven of them gave reasons, which included concerns that detection of SCD was not possible before 9 months and statements that they were not planning to have babies anymore. For mothers of young infants, 41 of them gave reasons for objecting to neonatal screening. Of these, 19 (46.3\%) reported that they knew they are not carriers of the sickle cell trait and so could not have babies with SCD, and $8(19.5 \%)$ were concerned that baby is still fragile and small for blood testing at that age.

More mothers in the primary group $\left(\chi^{2}\right.$ test, $\left.P<0.001\right)$ and in the secondary group $\left(\chi^{2}=9.61, P=0.002\right)$ were willing to have their babies screened at an immunization centre, rather than have their newborn remain in the birth health facility for more than 24 hours for the hemoglobin genotype test. The inconvenience of staying at a birth health facility for more than 24 hours to have their newborns screened would prevent at least $10-20 \%$ of mothers in this study from consenting to neonatal screening, relative to getting the test done at an immunization center. Sixty two (30.2\%) mothers of young infants and 16(8.9\%) mothers of affected children with SCD stated they would need permission from their husband or a family member such as grandparents and in-laws to test their baby's haemoglobin genotype $(P<0.001)$. One hundred and fifty-three $(74.6 \%)$ mothers of young infants and 156 (86.2\%) mothers of children with SCD believed neonatal testing for SCD would be beneficial $(P=0.003)$. 
Table 3. Health beliefs and perspectives of mothers in the study toward sickle cell disease

\begin{tabular}{|c|c|c|c|c|c|c|c|c|}
\hline & \multirow[b]{2}{*}{ Health beliefs statements } & \multirow[b]{2}{*}{ Group } & \multicolumn{5}{|c|}{ Scores } & \multirow{2}{*}{$\begin{array}{c}\text { Fisher's } \\
\text { exact } \\
\text { test }\end{array}$} \\
\hline & & & 1 & 2 & 3 & 4 & 5 & \\
\hline \multirow[t]{2}{*}{1} & $\begin{array}{l}\text { Sickle Cell Disease is a } \\
\text { serious disease }\end{array}$ & Primary group (\%) & 11.7 & 2.4 & 3.4 & 8.8 & 73.2 & $\begin{array}{c}20.7 \\
P<0.001\end{array}$ \\
\hline & & Secondary group (\%) & 7.2 & 6.6 & 3.9 & 22.7 & 59.7 & \\
\hline \multirow[t]{2}{*}{2} & $\begin{array}{l}\text { Having a child with sickle } \\
\text { cell disease would be very }\end{array}$ & Primary group (\%) & 14.1 & 2.9 & 8.8 & 15.6 & 57.1 & $\begin{array}{c}17.7 \\
P=0.001\end{array}$ \\
\hline & & Secondary group (\%) & 8.3 & 8.8 & 4.4 & 26.5 & 50.8 & \\
\hline \multirow[t]{2}{*}{3} & $\begin{array}{l}\text { My life would change if my } \\
\text { child had sickle cell disease }\end{array}$ & Primary group (\%) & 29.8 & 12.7 & 9.3 & 13.2 & 31.7 & $\begin{array}{c}4.7, \\
P=0.326\end{array}$ \\
\hline & & Secondary group (\%) & 26.5 & 17.1 & 6.6 & 19.3 & 30.4 & \\
\hline \multirow[t]{2}{*}{4} & $\begin{array}{l}\text { My children are at risk for } \\
\text { sickle cell disease }\end{array}$ & Primary group (\%) & 60 & 6.8 & 9.8 & 5.8 & 15.6 & $\begin{array}{c}15.5 \\
P=0.004\end{array}$ \\
\hline & $\begin{array}{l}\text { Before I had my first child } \\
\text { with SCD, I believed that } \\
\text { my children were at risk for } \\
\text { SCD }\end{array}$ & Secondary group (\%) & 58.6 & 17.1 & 3.9 & 8.3 & 11.6 & \\
\hline \multirow[t]{2}{*}{5} & $\begin{array}{l}\text { Sickle cell disease could } \\
\text { happen in my family. }\end{array}$ & Primary group (\%) & 67.3 & 8.8 & 7.8 & 6.8 & 7.8 & $\begin{array}{c}7.4, \\
P=0.116\end{array}$ \\
\hline & $\begin{array}{l}\text { Before I had my first child } \\
\text { with SCD, I believed SCD } \\
\text { could happen in my family }\end{array}$ & Secondary group (\%) & 58.0 & 16.0 & 6.1 & 9.4 & 10.5 & \\
\hline \multirow[t]{2}{*}{6} & $\begin{array}{l}\text { My spouse may be a carrier } \\
\text { of sickle cell trait. }\end{array}$ & Primary group (\%) & 61.0 & 13.2 & 9.8 & 3.9 & 10.7 & $\begin{array}{c}5.8, \\
P=0.211\end{array}$ \\
\hline & $\begin{array}{l}\text { Before I had my first child } \\
\text { with SCD, I believed that } \\
\text { my spouse may be a carrier } \\
\text { of sickle cell trait. }\end{array}$ & Secondary group (\%) & 54.7 & 14.7 & 7.2 & 8.8 & 13.3 & \\
\hline \multirow[t]{2}{*}{7} & $\begin{array}{l}\text { It is useful to know if I have } \\
\text { sickle cell trait }\end{array}$ & Primary group (\%) & 19.5 & 4.9 & 7.3 & 16.6 & 50.7 & $\begin{array}{c}13.9, \\
P=0.007\end{array}$ \\
\hline & & Secondary group (\%) & 11.0 & 6.1 & 1.7 & 21.0 & 59.7 & \\
\hline \multirow[t]{2}{*}{8} & $\begin{array}{l}\text { It is useful to know if my } \\
\text { spouse has sickle cell trait }\end{array}$ & Primary group (\%) & 16.1 & 5.4 & 7.3 & 22.9 & 47.3 & $\begin{array}{c}13.9, \\
P=0.007\end{array}$ \\
\hline & & Secondary group (\%) & 6.6 & 3.9 & 5.0 & 20.4 & 64.1 & \\
\hline \multirow[t]{2}{*}{9} & $\begin{array}{l}\text { Knowing the risk of having } \\
\text { a child with sickle cell } \\
\text { disease would change how I } \\
\text { plan a pregnancy }\end{array}$ & Primary group (\%) & 18.0 & 16.1 & 7.8 & 17.6 & 39.5 & $\begin{array}{c}22.5 \\
P<0.001\end{array}$ \\
\hline & & Secondary group (\%) & 11.0 & 5.5 & 3.9 & 23.2 & 55.8 & \\
\hline \multirow[t]{2}{*}{10} & $\begin{array}{l}\text { Testing for sickle cell } \\
\text { hemoglobin is painful and } \\
\text { difficult }\end{array}$ & Primary group (\%) & 48.3 & 12.2 & 16.1 & 6.3 & 16.1 & $\begin{array}{c}19.0 \\
P=0.001\end{array}$ \\
\hline & & Secondary group (\%) & 51.4 & 11.6 & 3.9 & 9.9 & 23.2 & \\
\hline \multirow[t]{2}{*}{11} & $\begin{array}{l}\text { My spouse would be hard } \\
\text { to convince to have testing }\end{array}$ & Primary group (\%) & 57.1 & 9.8 & 6.3 & 8.3 & 17.1 & $\begin{array}{c}6.3, \\
P=0.175\end{array}$ \\
\hline & & Secondary group (\%) & 45.3 & 14.4 & 9.4 & 9.9 & 20.4 & \\
\hline \multirow[t]{2}{*}{12} & $\begin{array}{l}\text { Screening a child for sickle } \\
\text { cell disease would be } \\
\text { expensive }\end{array}$ & Primary group (\%) & 46.8 & 15.1 & 19.0 & 6.3 & 11.2 & $\begin{array}{c}15.0 \\
P=0.004\end{array}$ \\
\hline & & Secondary group (\%) & 55.2 & 12.2 & 7.2 & 9.4 & 16.0 & \\
\hline
\end{tabular}

SCD - sickle cell disease

\section{FACTORS INFLUENCING KNOWLEDGE/HEALTH BELIEFS ABOUT SCD}

To determine factors that could have influenced the knowledge and perceptionsof these mothers about SCD, multiple linear regression analysis was run based on documented socio-demographic factors. These included level of education, religion, age and number of children. The level of education of mothers of young infants significantly predicted the knowledge base of the mothers, as knowledge base in- 


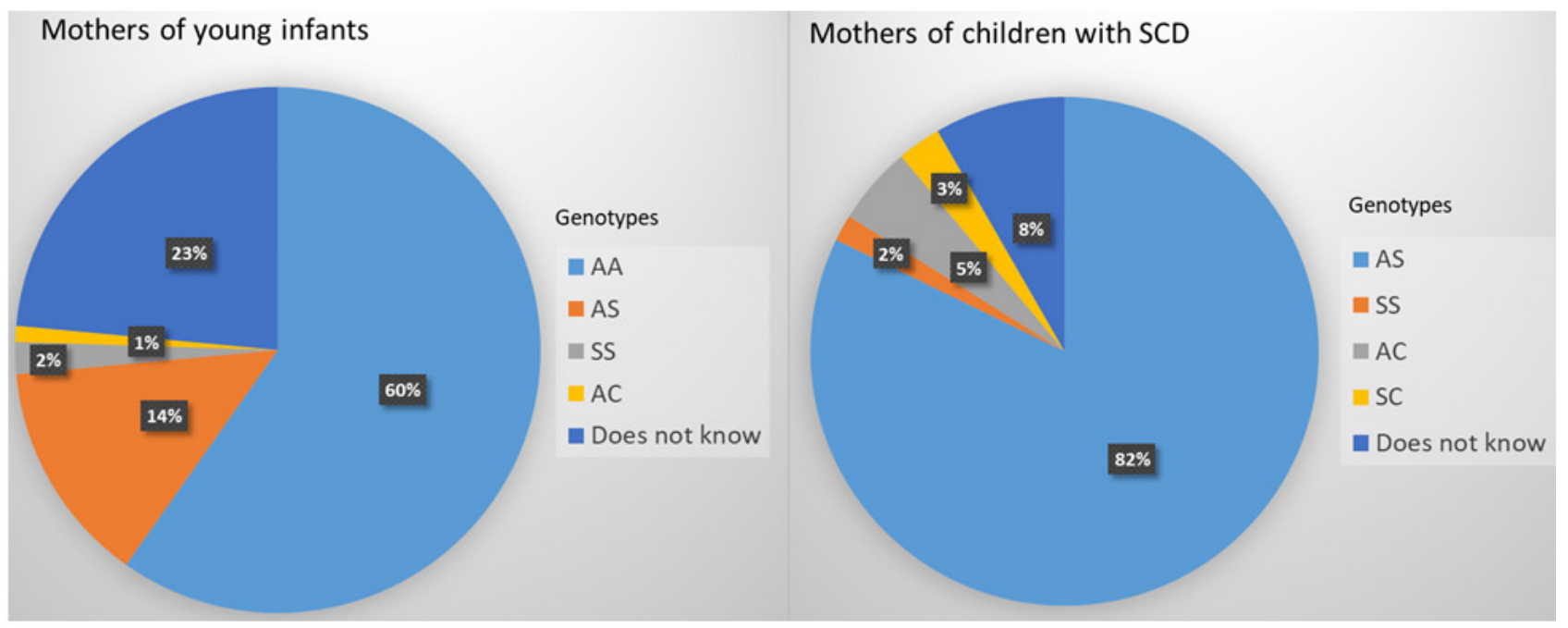

Figure 1. Self-declared genotypes of mothers of young infants and mothers of children with SCD.

Charts show that a significant proportion (23\%) of the mothers of young infants did not know their hemoglobin genotype and 5\% of mothers who are caregivers to SCD-affected children are patients themselves and $8 \%$ did not know their genotype.

Table 4. Proportion of women in both groups with positive responses to questions on acceptability and barriers of neonatal screening for SCD

\begin{tabular}{|c|c|c|c|c|}
\hline & & $\begin{array}{l}\text { Mothers of } \\
\text { infants } \\
(\mathrm{N}=205)\end{array}$ & $\begin{array}{l}\text { Mothers of SCD } \\
\text { affected children } \\
\qquad(\mathrm{N}=181)\end{array}$ & $x^{2}$ \\
\hline 1 & Knowledge of hemoglobin genotype & $156(76.1 \%)$ & $165(91.2 \%)$ & $\begin{array}{c}16.1 \\
P=0.001\end{array}$ \\
\hline 2 & Knowledge of spouse's hemoglobin genotype & $136(66.3 \%)$ & $163(90.1 \%)$ & $\begin{array}{l}31.1 \\
P=0.001\end{array}$ \\
\hline 3 & $\begin{array}{l}\text { Awareness that sickle cell disease can be diagnosed in the new } \\
\text { born period }\end{array}$ & $88(42.9 \%)$ & $84(46.4 \%)$ & $\begin{array}{c}1.68 \\
P=0.43\end{array}$ \\
\hline 4 & Acceptance of screening newborn for SCD & $133(64.9 \%)$ & $168(92.8 \%)$ & $\begin{array}{c}42.9 \\
P<0.001\end{array}$ \\
\hline 5 & $\begin{array}{l}\text { Willingness to allow newborn baby remain in the birth facility } \\
\text { for more than } 24 \text { hours for hemoglobin genotype test }\end{array}$ & $113(55.1 \%)$ & $147(81.2 \%)$ & $\begin{array}{c}28.8 \\
P<0.001\end{array}$ \\
\hline 6 & $\begin{array}{l}\text { Willingness to allow newborn baby have hemoglobin } \\
\text { genotype test at the immunization center }\end{array}$ & $154(75.1 \%)$ & $167(92.3 \%)$ & $\begin{array}{l}\text { 18.2., } \\
P<0.001\end{array}$ \\
\hline 7 & $\begin{array}{l}\text { Husband will be happy if mother permits hemoglobin } \\
\text { genotype test on baby in the newborn period }\end{array}$ & $133(64.9 \%)$ & $156(86.2 \%)$ & $\begin{array}{c}27.8 \\
P<0.001\end{array}$ \\
\hline 8 & $\begin{array}{l}\text { Husband will be happy if mother permits hemoglobin } \\
\text { genotype teston baby during an immunization visit }\end{array}$ & $145(70.7 \%)$ & 159 (87.8\%) & $\begin{array}{c}24.2 \\
P<0.001\end{array}$ \\
\hline 9 & $\begin{array}{l}\text { In need of permission of any family member to test baby's } \\
\text { hemoglobin genotype. }\end{array}$ & $62(30.2 \%)$ & $16(8.8 \%)$ & $\begin{array}{l}30.2 \\
P<0.001\end{array}$ \\
\hline 10 & $\begin{array}{l}\text { Acknowledgment of advantage in knowing the hemoglobin } \\
\text { genotype of baby at birth }\end{array}$ & $164(80 \%)$ & $158(87.3 \%)$ & $\begin{array}{l}3.9, \\
P=0.145\end{array}$ \\
\hline 11 & $\begin{array}{l}\text { Acknowledgment that the best time to diagnose SCD is in the } \\
\text { newborn period }\end{array}$ & $110(53.7 \%)$ & $95(52.5 \%)$ & $\begin{array}{c}2.42 \\
P=0.298\end{array}$ \\
\hline 12 & $\begin{array}{l}\text { Agreement that testing a baby in the newborn period for SCD } \\
\text { is beneficial }\end{array}$ & $153(74.6 \%)$ & $156(86.2 \%)$ & $\begin{array}{c}11.42 \\
P=0.003\end{array}$ \\
\hline 13 & $\begin{array}{l}\text { Acknowledgment of disadvantages in testing a baby for SCD } \\
\text { in the newborn period }\end{array}$ & $17(8.3 \%)$ & $27(14.9 \%)$ & $\begin{array}{l}17.60 \\
P=0.001\end{array}$ \\
\hline
\end{tabular}

SCD - sickle cell disease

creased with higher level of education $(P=0.013)$. Analysis of variance (ANOVA) of the knowledge scores of mothers of young infants based on level of education showed a significant difference between those with tertiary education and the two other groups $(P<0.001)$ (Figure 2). There was no significant difference between those with secondary education and a lower level of education $(P=0.726)$. However, for mothers of affected children, the differences among knowl- 


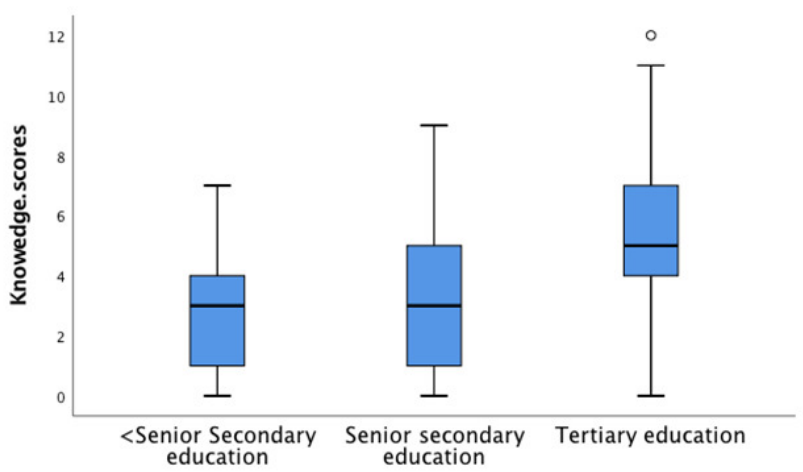

Figure 2. Knowledge scores of mothers of young infants based on their level of education.

Analysis of variance showed that mothers of young infants with tertiary education were significantly more knowledgeable about SCD than mothers with lower level of education $(P=0.001)$.

edge scores across the three levels of education were statistically significant $(P=0.001)$. The $\chi^{2}$ tests also showed that having tertiary education was significantly associated with the understanding of the genetic inheritance of SCD $(P=0.001)$ and having the correct health beliefs about SCD $(P=0.02)$. Logistic regression showed that higher level of education also positively influenced whether a mother knew her haemoglobin genotype and that of her spouse $(P=0.01)$.

\section{FACTORS INFLUENCING ACCEPTABILITY OF NEONATAL SCREENING FOR SCD}

Mothers who already had children affected by SCD were significantly more willing to have testing for their future babies (odds ratio $(\mathrm{OR})=6.7$, confidence interval $(C I)=3.552-12.638)$. Logistic regression using step-wise selection identified socio-demographic factors, knowledge and perceptions about SCD that could influence whether a mother was amenable or not to having her baby screened. The level of education of the mothers and knowledge/perceptions about SCD were important determinants of acceptance of screening. Mothers of young infants with tertiary education were less willing to accept neonatal screening than those with a lower level of education $(\mathrm{OR}=0.228$, $\mathrm{CI}=0.067-0.777)$. This was not the case for mothers with affected children. For this group, the level of education did not significantly influence acceptance of future testing. Among the mothers of young infants, those who believed SCD could happen in their families, and those who indicated it is useful to know if they have a sickle cell trait were more willing to accept screening than those who were of contrary beliefs or were undecided $(\mathrm{OR}=4.020$, $\mathrm{CI}=1.106-14.610)$ and $(\mathrm{OR}=3.681, \mathrm{CI}=1.535-8.826)$, respectively. Those who had heard that SCD could be diagnosed during the newborn period and those who thought diagnosing SCD in the newborn period is beneficial were also more willing to accept neonatal screening for their babies $(\mathrm{OR}=2.432, \mathrm{CI}=1.115-5.304, \quad P=0.0254)$ and $(\mathrm{OR}=4.468$, $\mathrm{CI}=1.873-10.654)$, respectively. Among mothers with affected children, those who had heard that SCD could be diagnosed during the newborn period were more willing to accept screening for their future babies $(\mathrm{OR}=27.27$, $\mathrm{CI}=6.326-117.558)$. For both groups of mothers, knowledge scores were not statistically significantly related to acceptance of testing.

\section{DISCUSSION}

This study sought to assess the adequacy of knowledge and perceptions of the target population with regards to SCD and newborn screening for SCD. We also went further to identify likely barriers and challenges to the successful implementation of the programme in Ibadan, south-western Nigeria. A pilot neonatal screening program would target mothers of young infants; this study's primary group. The SCD knowledge scores from this survey identified major deficiencies of knowledge in the primary group, relative to the secondary group, concerning the genetic inheritance of SCD, the best method of diagnosing SCD, and the age at which SCD begins to manifest. The primary group mothers were not well-informed about SCD.

Questions with the poorest performance in both sets of mothers were those identifying people of African descent as having the highest incidence of SCD and identifying stem cell transplant as the only cure for SCD. The secondary group had a higher knowledge score and a better understanding of SCD inheritance because they were already caregivers to children affected with SCD. This was also the case in a study carried out in Ghana where knowing a family member with the disease or the trait was associated with good knowledge of SCD. ${ }^{20}$

A major knowledge deficiency identified in this survey concerns the genetic component of SCD inheritance. The situation is similar to what one study observed in Uganda. Lack of understanding of SCD inheritance was reported as one of the barriers to improving SCD care and outcomes. ${ }^{21}$ Although the majority of primary group mothers in this study could recognize SCD as a blood disorder and were aware of haemoglobin genotype combinations in marriage that will not result in a child with SCD, most of them still lacked the understanding of the mode of inheritance of SCD. Most of them did not know a child has to inherit two $\mathrm{HbS}$ genes or one HbS gene and another mutated gene, one from each of the father and mother to have SCD. Concerning potential complications of SCD, it is worrisome that more than $70 \%$ of the secondary group mothers did not know SCD could cause stroke, infections and organ damage, and about half of them did not know jaundice and anaemia requiring blood transfusion were common features of SCD despite having children affected by the disease. These findings point to a deficiency in educating the general public, as well as caregivers, about SCD and its genetic inheritance.

This study also shows that mothers with tertiary education were much better informed about SCD than mothers with a lower level of education. This finding is not peculiar to mothers. A study conducted in locations in south-western Nigeria showed that only about half of the population had a moderate knowledge about SCD and most of them were students of tertiary institutions. ${ }^{22}$ This is not desirable for a country with the highest burden of the SCD in the world. It is however surprising that $42 \%$ of the mothers of 
children with SCD who participated in this study has a tertiary education. This points to the fact that mere knowledge does not necessarily translate to prevention.

The proportion of secondary group mothers with positive health beliefs about, and perspectives towards SCD and sickle cell trait was generally higher than that of the primary group mothers. This may be due to the experience they have had with SCD and also shows that the caregivers have learnt to cope with the condition. Some mothers in both groups strongly agreed they were aware that their children were at risk of SCD before getting married to their spouses. Also, the fact that about half of primary group mothers and some secondary group mothers reported that knowing their child's risk for SCD would not impact how they plan a pregnancy might be due to strong religious beliefs or a consequence of the inadequate understanding of the mothers about the morbidity associated with SCD. Olotu et al. ${ }^{23}$ reported a strong influence of societal, religious, personal and traditional beliefs of caregivers of children affected with SCD on their reproductive options. This is a major barrier for the country with regards to the control of SCD which can be surmounted through partnerships with cultural and religious leaders.

One other major reason for mothers' refusal of neonatal screening in this study was the knowledge that they and/ or their husbands are not carriers, meaning that they could not have babies with SCD. It is therefore, not surprising that mothers in the secondary group were more willing to accept neonatal screening. Acceptance of neonatal screening by primary group mothers in this study was just about $66 \%$ compared to a previous study at a catholic hospital in Benin, Nigeria, which had $99.7 \%$ acceptance. ${ }^{18}$ One of the reasons for the disparity in acceptance may be due to the fact that $71 \%$ of mothers in the Benin study did not know their genotype, and most likely, would not know their husband's genotype either. Among the primary group mothers in this study, the knowledge of the risk of having a family member with SCD and agreeing to the usefulness of knowing one's own sickle cell trait were both important for the mothers to accept screening for their newborns. However, about $20-30 \%$ of mothers in both groups did not see any benefit in knowing their sickle cell trait status nor that of their husbands. This study's counter-intuitive result that refusal to have neonatal screening was associated with increasing level of education can be explained by the fact that more educated mothers were more likely to know their own and their husband's genotype. They would not see the need to have neonatal testing if they are not carriers. In order to increase uptake, a government policy formulation with the 'opt out' approach may be put in place. That is, all babies are expected to be screened unless the parents do not consent to having their babies tested.

Awareness of the possibility of diagnosing SCD in the newborn period and its benefits was also an important factor in accepting newborn screening. One of the major reasons stated by the mothers for not accepting screening was the belief that it is not possible to diagnose SCD before nine months. This belief is likely due to prior SCD education efforts about diagnostic centers that utilize cellulose acetate paper electrophoresis, a method of SCD diagnosis that is only accurate after nine months. Although about $20-30 \%$ of the mothers in both groups believed that testing for SCD is painful, difficult and expensive, the fear of pain and the cost of screening were not found to be major factors against screening among most mothers in both groups.

Results showed that awareness of the mothers about SCD and their perspectives towards SCD and neonatal screening are significantly associated with willingness to participate in a neonatal screening program for the disease. Most mothers in both groups had never even heard of neonatal screening before the study. Identification of SCD, along with parental education on the care of affected infants had been shown to reduce mortality rate in Jamaica even before the introduction of penicillin prophylaxis or pneumococcal conjugate vaccines. Parental education on the detection of enlarged spleens and need for medical attention resulted in a $74 \%$ reduction in the death rate from acute splenic sequestration. ${ }^{24}$

A limitation of the present study is that it was conducted in health centers located in the Ibadan metropolitan area. Results may therefore not fully reflect the situation that obtains in rural communities, where awareness of, and knowledge about SCD are much lower. ${ }^{22}$

\section{CONCLUSIONS}

Neonatal screening programs for SCD in some other countries have helped to reduce morbidity and mortality in affected individuals. The study underscores the need to raise general awareness of SCD among young people before marriage. There is also a need for adequate education of parents, especially mothers so that they do not miss symptoms important to the early identification of SCD and the care of affected children. This is crucial to the success of any neonatal screening and comprehensive health care management program. Large scale public collaboration with the media,aimed at increasing health awareness talks and announcements, is necessary to engage the community on the benefits of early genetic testing of children and neonatal screening for SCD.

A large proportion of the primary group mothers in this study were found to need the permission of a family member before they would be able to agree to neonatal screening. This suggests the need to give pregnant women advanced notice of the screening test so that the mothers can get the permission they need beforehand. Informal lectures on SCD and the importance of neonatal screening should be incorporated into the antenatal care program at all levels of health care in Nigeria. This would also be a good time to obtain parental consents for testing of the newborns. It is also recommended that SCD education be given in children outpatient clinics and primary health centers where young mothers who are caregivers can be reached. Unfortunately, the burden of caring for sick children fall on mothers but adequate provision of social support for families with children with SCD could enable fathers participate more closely in the care of children with SCD.

Without broader access to high quality genotyping services and improved public awareness of recent advances in the care of SCD, there is always a risk of genetic discrimination. A personalized approach to genetic counseling and prenatal testing with adequate provision of support for 
families would allow for improved planning since the true birth incidence can only be determined by large scale population screening. While a government policy formulation with the 'opt out' approach may increase uptake, the inadequacy of health systems in Nigeria could leave vulnerable parents and SCD neonates at risk of social stigma.

Moreover, fewer than $40 \%$ of births in Nigeria occur in health care facilities, ${ }^{25,26}$ and most of these occur in public sector facilities. ${ }^{27}$ Many women give birth in other centers such as faith homes, privately-owned hospitals and traditional nursing homes. More than $60 \%$ of births occur at home, especially in the rural areas. ${ }^{27}$ The integration of SCD screening into the current immunization schedule of Nigeria would make it easier to access newborns. Such integration with the immunization schedule would also make it easier for follow-up, in terms of collection of results and appropriate referrals for affected children. While only about $25 \%$ of Nigerian children are fully immunized by the age of 12-23 months, about $80 \%$ in that age range would have had at least one vaccination. ${ }^{27}$ In a study based in Uganda ${ }^{21}$ a major impediment to enrollment for early care of neonates with SCD was the inability of providers to communicate test results to about $40 \%$ to $50 \%$ of parents of affected children, as they could not be reached on telephone. This reduced the subsequent impact of the screening for SCD. In Nigeria, many mothers will bring their babies back for other vaccination appointments.

With an estimated $32.2 \%$ increase in the number of newborns born with sickle cell anemia between 2010 and 2050 and a lack of public health infrastructure to support these children, Nigeria is in dire need of policies that can improve management of the disease. ${ }^{28}$ Our findings support a model for SCD screening in Nigeria that would include the following elements:

- Community education on SCD and newborn screening for SCD preceding the introduction of the programme and running alongside with on-going implementation to facilitate acceptance.

- Introduction of counselling about neonatal screening for SCD and obtaining consent from mothers, fathers and significant others during ante-natal care.

- Deployment of the neonatal screening program at immunization centers. This would result in better uptake among mothers.

- Integration of SCD screening with the current immunization schedule of Nigeria. This would make it easier to access newborns and also support scaling up of the program at national level.

- Building local capacity to improve uptake of genetic testing and premarital counseling for Sickle Cell Disease among young adults
Universal neonatal screening in African nations would be one of the most effective methods to reduce excess mortality and morbidity of SCD in children under five. ${ }^{29}$ Regional and pilot screening programs in Ghana, ${ }^{16}$ The Republic of Benin, ${ }^{30}$ and Angola ${ }^{31}$ have shown remarkable results. With these guidelines, the proposed neonatal screening model can be pilot-tested in Ibadan and perhaps other regions of the country, with adequate support of families provided by Advocacy groups such as Sickle Cell Hope Alive Foundation. Adaptations to this model can be made where necessary based on any contextual differences that may be observed in different parts of the country. These will set the stage to scale up neonatal screening throughout the country by the Federal Government as a national priority. Following successful implementation in Nigeria, the model may also be tested in other countries in West Africa and appropriate adaptations made based on contextual considerations peculiar to each country. If universal screening began in 2015, Nigeria would have had the potential to save an estimated 3.3 million lives by $2050 .^{28}$

\section{ACKNOWLEDGEMENTS}

The study protocol was approved by the Ethics Review Committee of the University of Ibadan, Nigeria and the Institutional Review Board of the University of Chicago. We are grateful for the assistance of Sickle Cell Hope Alive Foundation (SCHAF), Nigeria.

\section{FUNDING}

This research received financial support from The University of Chicago Pritzker School of Medicine Summer Research Program, The Doris Duke Charitable Foundation and NIH D43 TW009112.

\section{COMPETING INTEREST}

The authors have completed the Unified Competing Interest form at http://www.icmje.org/coi disclosure.pdf and declare no conflict of interest.

\section{CORRESPONDENCE TO:}

Oluwatoyin Aduke Babalola (BSc, MSc, PhD)

P.O Box 6107

Agodi Gate, Ibadan

Oyo State, Nigeria

praisebab2@gmail.com 


\section{REFERENCES}

1. Galadanci N, Wudil BJ, Balogun TM, et al. Current sickle cell disease management practices in Nigeria. Int Health. 2013;6(1):23-28. doi:10.1093/inthealth/iht $\underline{022}$

2. World Health Organization. Sickle Cell Anaemia. WHO Fifty-Ninth World Assembly, A59/9; 2006.

3. Leikin SL, Gallagher D, Kinney TR, Sloane D, Klug P, Rida W. Mortality in children and adolescents with sickle cell disease. Cooperative Study of Sickle Cell Disease. Pediatrics. 1989;84:500-508.

4. Quinn CT, Rogers ZR, McCavit TL, Buchanan GR. Improved survival of children and adolescents with sickle cell disease. Blood. 2010;115(17):3447-3452. do i:10.1182/blood-2009-07-233700

5. Griffiths PD, Mann JR, Darbyshire PJ, Green A. Evaluation of eight and a half years of neonatal screening for haemoglobinopathies in Birmingham. BMJ. 1988;296(6636):1583-1585. doi:10.1136/bmj.29 6.6636 .1583

6. Vichinsky E, Hurst D, Earles A, Kleman K, Lubin B. Newborn screening for sickle cell disease: effect on mortality. Pediatrics. 1988;81:749-755.

7. King L, Knight-Madden J, Reid M. Newborn screening for sickle cell disease in Jamaica: a review past, present and future. West Indian Med J. 2014;63:147-150.

8. Brandelise S, Pinheiro V, Gabetta CS, Hambleton I, Serjeant B, Serjeant G. Newborn screening for sickle cell disease in Brazil: The Campinas Experience. Clin Lab Haematol. 2004;26(1):15-19. doi:10.1111/j.0141-9 854.2003.00576.x

9. Bunn HF. Pathogenesis and treatment of sickle cell disease. N Engl J Med. 1997;337(11):762-769. doi:10.1 056/nejm199709113371107

10. Serjeant GR. Sickle-cell disease. Lancet. 1997;350(9079):725-730. doi:10.1016/s0140-6736(9 7)07330-3

11. Singhal A, Thomas P, Kearney T, Venugopal S, Serjeant G. Acceleration in linear growth after splenectomy for hypersplenism in homozygous sickle cell disease. Arch Dis Child. 1995;72(3):227-229. doi:1 $\underline{0.1136 / \text { adc. } 72.3 .227}$

12. Gladwin MT, Sachdev V, Jison ML, et al. Pulmonary hypertension as a risk factor for death in patients with sickle cell disease. $N$ Engl J Med. 2004;350(9):886-895. doi:10.1056/nejmoa035477
13. Ohene-Frempong K, Weiner SJ, Sleeper LA, Miller ST, Embury S, Moohr JW. Cerebrovascular accidents in sickle cell disease: rates and risk factors. Blood. 1998;91:288-294.

14. Schnog JB, Duits AJ, Muskiet FAJ, Cate H, Rojer RA, Brandjes DPM. Sickle cell disease; a general overview. Neth J Med. 2004;62:364-374.

15. Dennis-Antwi J, Dyson S, Ohene-Frempong K. Healthcare provision for sickle cell disease in Ghana: challenges for the African context. Diversity in Health and Social Care. 2008;5:241-254.

16. Ohene-Frempong K, Oduro J, Tetteh H, Nkrumah F. Screening newborns for sickle cell disease in Ghana. Pediatrics. 2008;121(Supplement 2):S120.2-S121. doi:10.1542/peds.2007-2022uuu

17. Grosse SD, Odame I, Atrash HK, Amendah DD, Piel FB, Williams TN. Sickle cell disease in Africa. Am I Prev Med. 2011;41(6):S398-S405. doi:10.1016/j.amepr e.2011.09.013

18. Odunvbun ME, Okolo AA, Rahimy CM. Newborn screening for sickle cell disease in a Nigerian hospital. Public Health. 2008;122(10):1111-1116. doi:10.1016/ j.puhe.2008.01.008

19. Federal Ministry of Health, Nigeria. Federal Republic of Nigeria Revised National Health Policy. Published 2004. Accessed August 13, 2017. http://chel d.org/wp-content/uploads/2012/04/Nigeria-RevisedNational-Health-Policy-2004.pdf

20. Boadu I, Addoah T. Knowledge, beliefs and attitude towards sickle cell disease among university students. J Community Med Health Educ. 2018;8:1.

21. Green NS, Mathur S, Kiuli S, Makani J, Fashakin V, LaRussa P. Family, community, and health system. Considerations for Reducing the burden of pediatric sickle cell disease in Uganda through newborn screening. Glob Pediatr Health. 2016;3:16637767. do $\mathrm{i}: 10.1177 / 2333794 \mathrm{X} 16637767$

22. Babalola OA, Aderemi AT, Odetunde A, Okedere B, Falusi AG. Sickle Cell Disease awareness in Southwestern Nigeria (Published abstract, SCDAA 44th Annual National Convention, Baltimore, Maryland, USA).

23. Oluwanisola O. Qualitative appraisal of reproductive decision-making among couples with increased risk of having a child with sickle cell disease. Published online 2016. 
24. Grosse SD, Atrash HK, Odame I, Amendah D, Piel $\mathrm{FB}$, Williams TN. The Jamaican historical experience of the impact of educational interventions on sickle cell disease child mortality. Am J Prev Med.

2012;42(6):e101-e103. doi:10.1016/j.amepre.2012.0 3.005

25. Austin A, Fapohunda B, Langer A, Orobaton N. Trends in delivery with no one present in Nigeria between 2003 and 2013. Int J Womens Health. 2015;7:345-356. doi:10.2147/ijwh.s79573

26. Abimbola S, Okoli U, Olubajo O, Abdullahi MJ, Pate MA. The midwives service scheme in Nigeria. PLoS Med. 2012;9(5):e1001211. doi:10.1371/journal.p med.1001211

27. Nigeria: 2013 demographic and health survey key findings. Accessed June 20, 2017. https://dhsprogra m.com/pubs/pdf/SR213/SR213.pdf
28. Piel FB, Hay SI, Gupta S, Weatherall DJ, Williams TN. Global burden of sickle cell anaemia in children under five, 2010-2050: modelling based on demographics, excess mortality and interventions. PLoS Med. 2013;10(7):e1001484. doi:10.1371/journa l.pmed.1001484

29. Makani J, Soka D, Rwezaula S, et al. Health policy for sickle cell disease in Africa: experience from Tanzania on interventions to reduce under-five mortality. Trop Med Int Health. 2014;20(2):184-187. $\underline{\mathrm{d}}$ oi:10.1111/tmi.12428

30. Rahimy MC, Gangbo A, Ahouignan G, Alihonou E. Newborn screening for sickle cell disease in the Republic of Benin. J Clin Pathol. 2008;62(1):46-48. do i:10.1136/jcp.2008.059113

31. McGann PT, Grosse SD, Santos B, et al. A CostEffectiveness Analysis of a Pilot Neonatal Screening Program for Sickle Cell Anemia in the Republic of Angola. J Pediatr. 2015;167(6):1314-1319. doi:10.101 6/j.jpeds.2015.08.068 